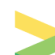
Research Square

\title{
Evaluation of mitochondrial membrane potential and DNA integrity in Catfish Pseudoplatystoma magdaleniatum, when exposed for prolonged times to different concentrations of ibuprofen.
}

Sara E. Gallego Ríos ( $\square$ sara.gallego@udea.edu.co)

Universidad de Antioquia https://orcid.org/0000-0002-5143-1869

Gustavo A. Peñuela

Universidad de Antioquia

Research Article

Keywords: Fish, Flow cytometry, Blood, NSAID, Ibuprofen

Posted Date: March 16th, 2021

DOI: https://doi.org/10.21203/rs.3.rs-274428/v1

License: (a) (i) This work is licensed under a Creative Commons Attribution 4.0 International License. Read Full License 


\section{Abstract}

There are few studies to date that determine the effects of ibuprofen on mitochondrial membrane potential $(\triangle \Psi \mathrm{M})$ and DNA integrity in neotropical fish. The objective of this study is to determine if four months' exposure to ibuprofen in different concentrations $(25$ and $50 \mu \mathrm{g} / \mathrm{L}$ ) produces effects on $\triangle \Psi \mathrm{M}$ and alters the integrity of DNA in striped catfish Pseudoplatystoma magdaleniatum. For this study, the fish were placed in tanks with water at constant concentrations of 0 (control), 25, and $50 \mu \mathrm{g} / \mathrm{L}$ of ibuprofen for four months. Subsequently, blood samples were taken for analysis of $\triangle \Psi \mathrm{M}$ and DNA integrity, using a flow cytometer LSRFortessa BD Biosciences. After four months of exposure to ibuprofen at different concentrations, the results showed no increase in Low $\triangle \Psi \mathrm{M}$, indicating that there are no alterations in the mitochondrial membrane potential. On the other hand, the percentages of DNA damage were below 0.39 , which indicates that there were no alterations in DNA integrity. It is possible that under the conditions in which this study was conducted (ibuprofen levels, exposure time), they are not sufficient to demonstrate the effects caused by this drug. Higher ibuprofen levels and/or longer exposures may be required to determine alteration in $\triangle \Psi M$ and DNA integrity. Flow cytometric analysis for these types of samples is a fast, specific, and reliable technique, compared to traditional methods.

\section{Introduction}

The function of pharmaceuticals is as medicines or to improve the quality of daily life (Giang et al. 2018; AguilarRomero et al. 2020). However, their presence in aquatic environments and their possible harmful effects on aquatic organisms have caused concern in recent years (Liu et al. 2020). The main entry routes for pharmaceuticals to aquatic environments are wastewater treatment plants due to their incomplete disposal (Montagner and Jardim 2011; Giang et al. 2018; Meijide et al. 2018; García-Cambero et al. 2019; Aguilar-Romero et al. 2020), and to a lesser extent, the combination of untreated rivers and runoff waters (González-Mira et al. 2016), aquaculture, and pharmaceutical manufacturing sites (Liu et al. 2020). Conventional wastewater treatment plants are not designed to eliminate most pharmaceutical products (Tiedeken et al. 2017), most of them are also persistent due to their continuous diffusion in the aquatic environment, which can remain dissolved in the water column or accumulate in sediments (González-Mira et al. 2016). Most of these compounds and their metabolites are biologically active (Sathishkumar et al. 2020) and can cause alterations in aquatic organisms exposed for long periods, causing endocrine alterations, genotoxicity, carcinogenicity, and fetal malformations, among others (Giang et al. 2019; Liu et al. 2020)

Ibuprofen is a non-selective non-steroidal anti-inflammatory drug (NSAID), this drug reversibly inhibits the synthesis of prostanoids (prostaglandins, prostacyclins, and thromboxanes) (González-Mira et al. 2016), by nonselectively inhibiting cyclooxygenase 1 and 2 enzymes and blocking the synthesis of prostaglandins and thromboxanes (Motov et al. 2020); Ibuprofen interferes with the cyclooxygenase pathway, decreasing the catalysis of prostaglandin biosynthesis from arachidonic acid (Parolini 2020). This drug can cause alterations in reproduction and development (Xia et al. 2017), oxidative stress, hematological changes, and DNA damage in fish (Mathias et al. 2018).

The striped catfish Pseudoplatystoma magdaleniatum is an endemic species and the second most commercially important in the Colombian fishery. However, it is among the critically endangered species (Mojica et al. 2012), mainly due to habitat degradation, embalming of rivers, overfishing, deforestation, and organic and inorganic contamination (Mojica et al. 2016; Herrera-Cruz et al. 2019). This fish inhabits the Magdalena and 
Cauca basins, the main rivers of Colombia; historically, these basins have presented unsolved environmental problems, derived from deforestation, erosion, and contamination by solid and liquid waste (Galvis and Mojica 2007; Noreña-Ramirez et al. 2012; Zapata et al. 2015; Tejeda-Benítez et al. 2018). This threatens both the economy of the communities where the catfish live, where it is a main source of work, income, and their food security as a source of food (Friedrich-Ebert-Stiftung and Foro Nacional Ambiental 2015).

The Magdalena river basin is the main recipient of domestic wastewater, as well as contaminated water derived from pesticides used in crops, illegal gold extraction, and some industries such as oil refining, tanneries (TejedaBenítez et al. 2018). The investigations carried out in the Magdalena river basin have been carried out mainly in the analysis of heavy metals, leaving aside the investigations for the determination of some pollutants such as pharmaceutical products in the Magdalena and Cauca rivers (Noreña-Ramirez et al. 2012; Tejeda-Benitez et al. 2016; Tejeda-Benítez et al. 2018). The main source of contamination in the Magdalena and Cauca basins is wastewater from the main cities Bogotá, Medellín, Cali, and Barranquilla (Galvis and Mojica 2007; Tejeda-Benitez et al. 2016). In these cities, some research has been carried out on the content of PPCPs in the waters, finding that the greatest contribution of pharmaceutical products is non-steroidal anti-inflammatory drugs, anticonvulsants, and antibiotics (Gracia-Lor et al. 2012; Hernández et al. 2015; Aristizabal-Ciro et al. 2017; Bedoya-Ríos et al. 2018; Arias 2019; Pemberthy et al. 2020).

Several studies have detected concentrations of ibuprofen in tributaries and effluents of wastewater treatment plants, surface waters, drinking water, sludge, and hospital effluents. Ibuprofen concentrations have been reported around the world in the range of 0.001 and $75.8 \mu \mathrm{g} / \mathrm{L}$. (Gutiérrez-Noya et al. 2020). Ibuprofen may be present in the Magdalena river basin, causing alterations in the catfish that inhabit these areas and possibly being one of the causes of their decrease in the basin. The determination of the possible alterations in the mitochondrial membrane potential $(\triangle \Psi \mathrm{M})$ and the integrity of the DNA can be determined by flow cytometry, since it is a fast and reliable technique to quantify and characterize some cell populations, allowing the evaluation of processes immunopathological in fish (Alzamora-Gonzales et al. 2015).

The $\triangle \Psi$ M regulates the synthesis of adenosine-tri-phosphate (ATP), the production of reactive oxygen species (ROS), the sequestration of calcium in the mitochondria, the import of mitochondrial proteins, and the dynamics of the mitochondrial (Luna-Ortiz et al. 2013; Zorova et al. 2018; Restrepo et al. 2019). $\Delta \Psi \mathrm{M}$ is important for many mitochondrial processes and is related to mitochondrial and cellular health (Allauca et al. 2019).

Because ibuprofen is one of the most widely consumed drugs in the world (Ngo and Bajaj 2020), it is possible that it is present in the main rivers of Colombia and is one of the possible causes of the decline of striped catfish $P$. magdaleniatum in the last four decades. For this, a controlled experimental study was carried out for four months with different doses $(0,25,50 \mu \mathrm{g} / \mathrm{L})$ of ibuprofen in males and females of $P$. magdaleniatum, determining the alterations in the mitochondrial membrane potential and the integrity of the DNA, by flow cytometry.

\section{Materials And Methods 2.1. Fish Husbandry}


The striped catfish Pseudoplatystoma magdaleniatum (Siluriformes: Pimelodidae) is manifested through sexual dimorphism, reproductive migrations with temporality for spawning (Arce et al. 2014), and not possessing scales. The catfish is nocturnal, feeds on fish, some arthropods, and seeds (Santamaría Merchán 2013).

All the fish were caught in the Cauca River, Colombia. Sexually mature striped catfish, P. magdaleniatum were used per experimental tank, in which they were divided into males and females (three male and three female catfish were distributed in individual tanks) with average weights and lengths of $1.86 \pm 0.49 \mathrm{~kg}$ and $61.14 \pm 4.76$ $\mathrm{cm}$ for males and $2.07 \pm 0.64 \mathrm{~kg}$ and $63.86 \pm 6.01 \mathrm{~cm}$ for females. All experimentation was carried out at the Fish Culture Research Institute of the University of Córdoba (CINPIC) located in Montería, in the department of Córdoba. The fish were acclimatized for two months in tanks of $3250 \mathrm{~m}^{3}$, with a 12/12 photoperiod throughout the year.

The fish were fed with live feed Astyanax sp (fed on demand), grown in fish farming. To guarantee the quality of the water in the ponds, Table 1, weekly using a portable multiparameter (HACH, Sension + MM15, USA): dissolved oxygen, temperature, $\mathrm{pH}$ and percentage of oxygen saturation; total alkalinity (Rice et al. 2017a); total hardness (Standard Methods 2340 C) (Rice et al. 2017b); and volatile solids and fixed solids (Standard Methods 2540 E) (Rice et al. 2017c); ammonia nitrogen and ammonia using a kit (API, USA).

Table 1

Water quality of the experimental units.

\begin{tabular}{|c|c|c|c|c|c|c|c|}
\hline Month & $\begin{array}{l}\text { Temperature } \\
\left({ }^{\circ} \mathrm{C}\right)\end{array}$ & $\begin{array}{l}\text { Oxygen } \\
\text { saturation } \\
\text { (\%) }\end{array}$ & $\mathrm{pH}$ & $\begin{array}{l}\text { Ammonium } \\
\left(\mathrm{NH}_{3} / \mathrm{NH}_{4}{ }^{+}\right)\end{array}$ & $\begin{array}{l}\text { Total } \\
\text { alkalinity } \\
\left(\mathrm{mg} / \mathrm{LaCO}_{3}\right)\end{array}$ & $\begin{array}{l}\text { Total } \\
\text { hardness } \\
\left(\mathrm{mg} / \mathrm{L} \mathrm{CaCO}_{3}\right)\end{array}$ & $\begin{array}{l}\text { Fixed } \\
\text { solids } \\
\text { (mg/L) }\end{array}$ \\
\hline 1 & $29.31 \pm 0.89$ & $\begin{array}{l}86.36 \pm \\
3.89\end{array}$ & $\begin{array}{l}7.60 \\
\pm \\
0.00\end{array}$ & $0.35 \pm 0.14$ & $64.95 \pm 4.88$ & $67.57 \pm 3.21$ & $\begin{array}{l}208.5 \pm \\
2.12\end{array}$ \\
\hline 2 & $28.54 \pm 0.38$ & $\begin{array}{l}91.85 \pm \\
4.25\end{array}$ & $\begin{array}{l}7.83 \\
\pm \\
0.20\end{array}$ & $0.42 \pm 0.30$ & $68.30 \pm 3.68$ & $72.78 \pm 6.16$ & $\begin{array}{l}213 \pm \\
9.90\end{array}$ \\
\hline 3 & $28.55 \pm 0.36$ & $\begin{array}{l}89.31 \pm \\
5.89\end{array}$ & $\begin{array}{l}7.93 \\
\pm \\
0.21\end{array}$ & $0.46 \pm 0.29$ & $69.95 \pm 5.59$ & $77.26 \pm 1.48$ & $\begin{array}{l}214 \pm \\
1.41\end{array}$ \\
\hline 4 & $28.98 \pm 0.43$ & $\begin{array}{l}91.06 \pm \\
2.33\end{array}$ & $\begin{array}{l}7.80 \\
\pm \\
0.00\end{array}$ & $0.42 \pm 0.13$ & $67.55 \pm 5.30$ & $75.60 \pm 6.14$ & $\begin{array}{l}212 \pm \\
5.66\end{array}$ \\
\hline \multicolumn{8}{|c|}{ Values are expressed as mean \pm SD. } \\
\hline SD sta & d deviation. & & & & & & \\
\hline
\end{tabular}

These species were caught with the authorizations required by current regulations, Framework Permit issued by the Autoridad Colombiana de Licencias Ambientales (ANLA) in Resolution 1461 of December 3, 2014. The number of samples was determined based on the considerations of the Ethics Committee for Animal Experimentation of the Universidad de Antioquia, with Act 89 of May 29, 2014, in which the minimum use of fish is recommended for the extraction, to minimize the impact on the capture of these fish, which have been devastated in the last decades. All animal experiments were by Directive 2010/63/EU of the European Parliament (Official Journal of the European Union 2010). 


\subsection{Experimental design}

The fish caught for the experimentation are fish of sexual maturity size, however, the breeding season waited; the experiment lasted four continuous months, the time necessary for this species to develop its gametes (Palacio 2009; Arce et al. 2014). The experimentation was carried out with three independent experiments, the fish were divided into three groups according to their exposure: 0 control, 25 and $50 \mu \mathrm{g} / \mathrm{L}$, the control group $(0 \mu \mathrm{g} / \mathrm{L})$ always remained below the limit of detection. Due to the photochemical degradation and absorption of ibuprofen by the fish, $50 \%$ of the water in the tanks was replaced weekly and the ibuprofen concentrations were readjusted in each tank. Water samples were taken in amber glass containers, kept at $4-6^{\circ} \mathrm{C}$ for 24 hours. Ibuprofen was quantified using an ultra-performance liquid chromatography-tandem mass spectrometer (UHPLC-MS/MS) following the modified EPA method 1694 (Environmental Protection Agency (EPA) et al. 2007).

The ibuprofen concentrations for the experiment were determined taking into account some environmental concentrations present in the tributaries $(<0.984-6.328 \mu \mathrm{g} / \mathrm{L})$ and effluents $(<0.065-0.491 \mu \mathrm{g} / \mathrm{L})$ of wastewater treatment plants (Kasprzyk-Hordern et al. 2009) and some rivers in the United Kingdom (1.681-33.764 $\mu \mathrm{g} / \mathrm{L}$ (Petrie et al. 2014)). Also, the sublethal LC50 (1/10 of LC50) of some similar species, $14.2 \mu \mathrm{g} / \mathrm{L}$, was taken into account (Saravanan et al. 2012). Taking into account the levels of this medically in the water and an estimate of the sublethal dose, a concentration of $25 \mu \mathrm{g} / \mathrm{L}$ and $50 \mu \mathrm{g} / \mathrm{L}$ was determined to evaluate the possible effects.

The concentrations of ibuprofen added were determined taking into account environmental concentrations present in the tributaries $(<0.984-6.328 \mu \mathrm{g} / \mathrm{L})$ and effluents $(<0.065-0.491 \mu \mathrm{g} / \mathrm{L})$ of wastewater treatment plants (Kasprzyk-Hordern et al. 2009) and some rivers in the United Kingdom $(1,681-33,764 \mu \mathrm{g} / \mathrm{L}$ (Petrie et al. 2014)). As well as sublethal LC50 (1/10 of LC 50) of some similar species $14.2 \mathrm{mg} / \mathrm{L}$ (Saravanan et al. 2012). Taking into account the ibuprofen levels in the water and an estimate of the sublethal dose, a concentration of $25 \mu \mathrm{g} / \mathrm{L}$ and $50 \mu \mathrm{g} / \mathrm{L}$ was determined to evaluate the possible effects on mitochondrial membrane potential and DNA integrity.

\subsection{Blood Sampling}

Blood samples were taken 14 days after the addition of ibuprofen and after four months. Blood samples were collected by a direct puncture in the tail vein with the help of a vacutainer; the tubes in which the samples were collected contained EDTA K2 anticoagulants. Blood samples were taken for each treatment and all samples were processed separately. Blood was drawn from each fish and kept for 1 hour at $4-6^{\circ} \mathrm{C}$ and in the absence of ultraviolet light until reaching the laboratory for analysis.

\subsection{Determination of Mitochondrial Membrane Potential $(\Delta \Psi \mathrm{M})$}

For the determination of $\triangle \Psi M$ in the blood samples, 3,3'-dihexyloxacarbocyanin iodide ( $\mathrm{DiOC}_{6}, \mathrm{Molecular}$ Probes by Life Technologies, Thermo Fisher Scientific) was used. This fluorescent dye is used for mitochondrial staining under the influence of the permeability transition (Rojas et al. 2000; Rieger et al. 2011). For analysis, a tube was used to add the $\mathrm{DIOC}_{6}$ in phosphate buffer (PBS) to a final concentration of $800 \mathrm{nM}$, then $10 \mu \mathrm{L}$ of blood was added. Subsequently, to stain the cells to simultaneously assess their viability, $1 \mu \mathrm{g} / \mathrm{mL}$ of propidium iodide (PI, Thermo Fisher Scientific) was added to each tube. The samples were incubated for 30 minutes and the $\triangle \Psi M$ was measured by flow cytometry (LSRFortessa, BD Biosciences). Subsequently separated in three ways according to the intensity of the $\mathrm{DIOC}_{6}$ in the Moflo XDP using a $70 \mu \mathrm{m}$ nozzle, at a frequency of 100 thousand 
$\mathrm{Hz}$, with a minimum efficiency of 98 for each of the three separations ways. The temporality analyzes had been made on the high uptake and intermediate uptake cells of $\mathrm{DIOC}_{6}$, Fig. 1.

The $\triangle \Psi \mathrm{M}$ of the blood was assessed with an adapted version of the protocol described by Zamzami et al. (1996). A polystyrene tube was used to deposit 3.3'-dihexyloxacarbocyanine iodide (DiOC6, Molecular Probes) in PBS at a final concentration of $80 \mathrm{nM}$ and 7-aminoactinomycin D (7-AAD, Molecular Probes) at a final concentration of $2 \mu \mathrm{g} / \mathrm{ml}$. The compounds were pipetted, and then, $10 \mu \mathrm{l}$ of blood were added, the final volume of the reaction was $300 \mu \mathrm{l}$. Subsequently, to stain the cells to simultaneously evaluate their viability, a final concentration of $1 \mathrm{mg} / \mathrm{ml}$ of propidium iodide (PI) (Molecular Probes, USA) was added. The samples were incubated for $30 \mathrm{~min}$, and $\triangle \Psi \mathrm{M}$ was measured using flow cytometry (LSRFortessa ${ }^{\mathrm{TM}}$, BD Biosciences). The samples were excited using a $488 \mathrm{~nm}$ solid phase laser, and fluorescence from DiOC6 and 7-AAD has detected at $530 / 30 \mathrm{~nm}$ and $630 / 30 \mathrm{~nm}$, respectively. The flow cytometry data were analyzed using FlowJo version 7.6.2 (FlowJo, LLC, USA) software.

\subsection{Determination of DNA Integrity}

DNA integrity was evaluated by PI staining. Cells were fixed with $300 \mu \mathrm{L}$ of $70 \%$ ethanol (Merck, Germany) prepared in PBS ( $\mathrm{pH} 7.4)$ for 12 hours at $4^{\circ} \mathrm{C}$. The samples were centrifuged $\left(500 \mathrm{~g}, 5\right.$ minutes, $\left.4^{\circ} \mathrm{C}\right)$ and the resulting granules were washed twice more with $3.0 \mathrm{~mL}$ of PBS. Cells were stained with PI $1 \mu \mathrm{g} / \mathrm{mL}$ in PBS with $0.37 \% \mathrm{w} / \mathrm{v}$ EDTA, $0.01 \% \mathrm{v} / \mathrm{v}$ of Triton X-100 and $200 \mathrm{U} / \mathrm{mL}$ of RNase A (Sigma-Aldrich). The samples were incubated for 30 minutes and DNA integrity was measured by flow cytometry (LSRFortessa, BD Biosciences) (Restrepo et al. 2019).

\subsection{Analysis of Flow Cytometry}

A flow cytometer with LSRFortessa equipment (BD Biosciences, San Jose, CA), using FlowJo 10.6 software (Tree Star Inc., Ashland, Oregon, United States) was used to perform the analyses. The determination of mitochondrial membrane damage was performed by excluding aggregates by selecting the cell population of interest after contrasting the size (FSH) and granularity (SSC) to select unique events. After performing this exclusion, $\mathrm{DiOC}_{6}{ }^{-}$ positive cells were compared with propidium iodide ( $\mathrm{PI}$ )-negative cells, differentiating between the populations of erythrocytes and leukocytes, Fig. 2.

For the determination of DNA integrity, an exclusion of aggregates was also performed by selecting the cell population of interest after contrasting the size (FSH) and granularity (SSC), to select the unique events. Once the unique events were selected, employing PI-A and PI-W, the single cells were selected to determine the DNA integrity employing the histogram, Fig. 3.

\subsection{Statistical Analysis}

Statistical analysis was performed using Statgraphics Centurion XVII (StatPoint Inc., USA). The evaluation of the normality of the continuous variables was performed via the Shapiro-Wilk test. Nonparametric statistics were applied to those variables that were not normally distributed. An analysis of variance (ANOVA) was used to evaluate the existence of significant differences between $\triangle \Psi M$ and DNA integrity. If this gave a statistically significant difference, a post-ANOVA by the least significant difference test (LSD-Fisher) was used. Statistical differences for $\mathrm{PI}+$ and $\triangle \Psi \mathrm{M}$ were analyzed by two-way analysis of variance (ANOVA) with exposure time, 
concentration, and "time x concentration" interaction as variables. For all statistical analyzes, the significance criterion was established at $p<0.05$.

\section{Results And Discussion}

Various studies have been carried out in fish on the alterations that ibuprofen present in the waters can cause. Finding increased glutathione-S-transferase activity in the kidney, reduced glutathione peroxidase activity, decreased white blood cell count, causing nephrotoxicity and immunosuppressive effect (Mathias et al. 2018), increased cardiac output in embryos, decreased cell density (Zhang et al. 2019), and a significant reduction in the hatching rate (Xia et al. 2017). So far, no publications have been found on the possible alterations on the integrity of the DNA in P. magdaleniatum caused by the presence of ibuprofen in the waters.

For this study, blood samples of striped catfish, Pseudoplatystoma magdaleniatum, collected from fish exposed to concentrations of $25 \mu \mathrm{g} / \mathrm{L}$ and $50 \mu \mathrm{g} / \mathrm{L}$ of ibuprofen for four consecutive months, and control fish without exposure, were analyzed. Environmental concentrations were used, as in some of the studies mentioned above. An analysis of $\triangle \Psi \mathrm{M}$ was performed, as an indicator of cell viability. This reflects the hydrogen pumping through the internal membrane in the electron transport and oxidative phosphorylation processes. These processes are necessary for the production of ATP, which means that mitochondrial dysfunction is closely related to an alteration in the membrane potential that would cause a decrease in the production of ATP (Padmini and Usha Rani 2011).

We analyzed the variations between the $\triangle \Psi \mathrm{M}$ and cells with damage to the cell membrane, positive for PI. Table 2 shows the results for a two-way analysis of variance (ANOVA), where it is observed that there is no statistically significant difference in the $\mathrm{PI}+$ samples between the different treatments, nor in the comparisons concerning the four months of exposure. For the $\triangle \Psi \mathrm{M}$ there is no statistically significant difference between the High $\triangle \Psi \mathrm{M}$, however, comparing the $\triangle \Psi \mathrm{M}$ between the treatments and after exposure, the Medium $\triangle \Psi \mathrm{M}$ presents

statistically significant differences $(p<0.05)$ with an increase in the percentage after four months of treatment, as well as a decrease in the percentages of Low $\triangle \Psi M$ after four months of exposure to ibuprofen. Despite this difference between Medium and Low $\triangle \Psi \mathrm{M}$, there was no decrease in $\triangle \Psi \mathrm{M}$ after four months of treatment with ibuprofen, therefore, this drug can be indicated at concentrations of 25 and $50 \mu \mathrm{g} / \mathrm{L}$, for four months, not produces loss of mitochondrial function (Blanco and López-Armada 2005). 
Table 2

Variations in mitochondrial membrane potential $(\triangle \Psi \mathrm{M})$ and $\mathrm{Pl}+$, concerning exposure time and concentrations of ibuprofen to which P. magdaleniatum were exposed.

\begin{tabular}{|llll|}
\hline Parameter & \multicolumn{3}{l|}{ Source of variation } \\
\cline { 2 - 4 } & Time & Concentration & Interactions \\
& p-value & p-value & p-value \\
\hline $\mathrm{PI}+$ & 0.96 & 0.32 & 0.79 \\
\hline High $\triangle \Psi \mathrm{M}$ & 0.93 & 0.83 & 0.23 \\
\hline Medium $\triangle \Psi \mathrm{M}$ & $0.001 *$ & 0.43 & 0.36 \\
\hline Low $\triangle \Psi \mathrm{M}$ & $0.01 *$ & 0.54 & 0.43 \\
\hline p $<0.05$, ANOVA for exposure time and concentration. \\
\hline *Significant factor.
\end{tabular}

Table 3 shows the analysis of $\triangle \Psi \mathrm{M}$, the median fluorescence intensity, determined by sex and ibuprofen concentration in the different analysis times. For females exposed to $25 \mu \mathrm{g} / \mathrm{L}$ of ibuprofen and presenting ratios 0.75 and 076 (High $\triangle \Psi \mathrm{M}$ and Medium $\triangle \Psi \mathrm{M}$, respectively), it is indicated that at the time of the assay their leukocytes had a less mitochondrial function at time zero. However, females exposed to $50 \mu \mathrm{g} / \mathrm{L}$ and presenting a ratio of 1.63 had mitochondrial hyperactivity at time zero. Both events are due to a type of stress that can be interpreted respectively as depolarization and hyperpolarization. Meanwhile, the analyses performed after four months of exposure to this ibuprofen show, for males exposed to a concentration of $50 \mu \mathrm{g} / \mathrm{L}$ with ratios of 0.68 and 0.70 (High $\triangle \Psi \mathrm{M}$ and Medium $\triangle \Psi \mathrm{M}$, respectively), that $32 \%$ and $30 \%$ of their leukocytes present lower $\mathrm{DIOC}_{6}$ uptake than the control at the time of the test. For those that have a ratio above 1 (High $\Delta \Psi \mathrm{M}$ ), there are 12,28 , and $34 \%$ of leukocytes with some hyperpolarization and, as these do not exceed 1.5 , this may be due to the fluctuations of the test. 
Table 3

Percentage of mitochondrial membrane potential $(\triangle \Psi \mathrm{M})$, median fluorescence intensity, and ratio, related by sex and ibuprofen concentration in the different analysis times applied to $P$. magdaleniatum.

\begin{tabular}{|c|c|c|c|c|c|c|c|c|c|c|}
\hline \multirow[t]{3}{*}{ Sex } & \multirow{2}{*}{$\begin{array}{l}\text { Concentration } \\
(\mu \mathrm{g} / \mathrm{L})\end{array}$} & \multicolumn{9}{|c|}{ Time zero } \\
\hline & & $\begin{array}{l}\text { High } \\
\triangle \Psi M \\
(\%)\end{array}$ & $\begin{array}{l}\text { MFI } \\
\text { High }\end{array}$ & Ratio & $\begin{array}{l}\text { Medium } \\
\triangle \Psi \mathrm{M} \\
(\%)\end{array}$ & $\begin{array}{l}\text { MFI } \\
\text { Medium }\end{array}$ & Ratio & $\begin{array}{l}\text { Low } \\
\triangle \Psi \mathrm{M} \\
(\%)\end{array}$ & $\begin{array}{l}\text { MFI } \\
\text { Low }\end{array}$ & Ratio \\
\hline & 0 control & $\begin{array}{l}12.0 \\
\pm 4.8 \\
a b\end{array}$ & 3561 & 1.00 & $\begin{array}{l}30.0 \pm \\
6.2^{a b}\end{array}$ & 1972 & 1.00 & $\begin{array}{l}2.9 \\
\pm 3.7 \\
a b\end{array}$ & 1076 & 1.00 \\
\hline Female & 25 & $\begin{array}{l}9.1 \\
\pm 2.9 \\
a\end{array}$ & 3352 & 0.76 & $\begin{array}{l}22.6 \pm \\
5.9^{a}\end{array}$ & 2210 & 0.75 & $\begin{array}{l}1.1 \\
\pm 1.0 \\
a\end{array}$ & 568 & 0.36 \\
\hline Male & & $\begin{array}{l}10.9 \\
\pm 1.0 \\
a b\end{array}$ & 3547 & 0.91 & $\begin{array}{l}32.9 \pm \\
7.3^{a b}\end{array}$ & 1957 & 1.10 & $\begin{array}{l}1.2 \\
\pm 0.8 \\
b\end{array}$ & 1154 & 0.42 \\
\hline Female & 50 & $\begin{array}{l}19.6 \\
\pm \\
12.4 \\
b\end{array}$ & 3613 & 1.63 & $\begin{array}{l}17.8 \pm \\
3.3^{a}\end{array}$ & 2250.5 & 0.59 & $\begin{array}{l}0.5 \\
\pm 0.2 \\
a\end{array}$ & 525.5 & 0.00 \\
\hline Male & & $\begin{array}{l}13.1 \\
\pm 6.0 \\
a b\end{array}$ & 3497 & 1.09 & $\begin{array}{l}37.2 \pm \\
7.1^{a b c}\end{array}$ & 1777 & 1.24 & $\begin{array}{l}4.4 \\
\pm 3.6 \\
a b\end{array}$ & 1181 & 1.51 \\
\hline \multirow[t]{3}{*}{ Sex } & Concentration & \multicolumn{9}{|c|}{ Four months } \\
\hline & & $\begin{array}{l}\text { High } \\
\triangle \Psi M \\
(\%)\end{array}$ & $\begin{array}{l}\text { MFI } \\
\text { High }\end{array}$ & Ratio & $\begin{array}{l}\text { Medium } \\
\triangle \Psi \mathrm{M} \\
(\%)\end{array}$ & $\begin{array}{l}\text { MFI } \\
\text { Medium }\end{array}$ & Ratio & $\begin{array}{l}\text { Low } \\
\triangle \Psi \mathrm{M} \\
(\%)\end{array}$ & $\begin{array}{l}\text { MFI } \\
\text { Low }\end{array}$ & Ratio \\
\hline & 0 control & $\begin{array}{l}11.8 \\
\pm 1.6 \\
a b\end{array}$ & 4200 & 1.00 & $\begin{array}{l}75.7 \pm \\
3.1^{\mathrm{d}}\end{array}$ & 2070 & 1.00 & $\begin{array}{l}0.3 \\
\pm 0.4 \\
a\end{array}$ & 686 & 1.00 \\
\hline Female & 25 & $\begin{array}{l}13.2 \\
\pm 4.5 \\
a b\end{array}$ & 3670 & 1.12 & $\begin{array}{l}74.7 \pm \\
3.6^{d}\end{array}$ & 1995 & 0.99 & $\begin{array}{l}0.5 \\
\pm 0.7 \\
a\end{array}$ & 710 & 1.52 \\
\hline Male & & $\begin{array}{l}15.1 \\
\pm 6.0 \\
a b\end{array}$ & 4242 & 1.28 & $\begin{array}{l}73.6 \pm \\
2.9^{\mathrm{d}}\end{array}$ & 2340 & 0.97 & $\begin{array}{l}0.1 \\
\pm 0.1 \\
a\end{array}$ & 523 & 0.26 \\
\hline
\end{tabular}

Mean \pm SD.

High $\triangle \Psi$ M: samples with high mitochondrial membrane potential.

Medium $\triangle \Psi$ M: samples with medium mitochondrial membrane potential.

Low $\triangle \Psi$ M: samples with low mitochondrial membrane potential.

MFI: median fluorescence intensity.

Different lowercase letters in the columns indicate statistically significant differences $(p<0.05)$. 


\begin{tabular}{|c|c|c|c|c|c|c|c|c|c|c|}
\hline Female & 50 & $\begin{array}{l}15.9 \\
\pm \\
11.3 \\
a b\end{array}$ & 3941 & 1.34 & $\begin{array}{l}69.1 \pm \\
11.4 \mathrm{~cd}\end{array}$ & 2418.5 & 0.91 & $\begin{array}{l}0.0 \\
\pm 0.0 \\
\text { ab }\end{array}$ & 396 & 0.13 \\
\hline Male & & $\begin{array}{l}8.0 \\
\pm 4.8 \\
a\end{array}$ & 4425 & 0.68 & $\begin{array}{l}53.1 \pm \\
37.8 \mathrm{bcd}\end{array}$ & 2322 & 0.70 & $\begin{array}{l}0.1 \\
\pm 0.0 \\
a\end{array}$ & 499 & 0.16 \\
\hline \multicolumn{11}{|c|}{ Mean \pm SD. } \\
\hline \multicolumn{11}{|c|}{ High $\triangle \Psi$ M: samples with high mitochondrial membrane potential. } \\
\hline \multicolumn{11}{|c|}{ Medium $\triangle \Psi$ M: samples with medium mitochondrial membrane potential. } \\
\hline \multicolumn{11}{|c|}{ Low $\triangle \Psi \mathrm{M}$ : samples with low mitochondrial membrane potential. } \\
\hline \multicolumn{11}{|c|}{ MFI: median fluorescence intensity. } \\
\hline \multicolumn{11}{|c|}{ Different lowercase letters in the columns indicate statistically significant differences $(p<0.05)$. } \\
\hline
\end{tabular}

So far, no comparable results have been found where the analysis for $\triangle \Psi \mathrm{M}$ in blood samples is performed by flow cytometry. However, the determination of $\Delta \psi \mathrm{M}$ by flow cytometry is suggested as a biomarker due to its higher specificity and quick quantitative assessment of the possible risk of exposure to this type of pharmaceutical (Padmini and Usha Rani 2011).

Table 4 shows the integrity of the DNA, the results for time zero and after four months of exposure to ibuprofen, do not present statistically significant difference between the different treatments, and no effect on DNA is evidenced, since, after four months of exposure to ibuprofen, the average for males and females is $92.30 \%$ for $2 n$, which indicates that the vast majority do not present fragmentation in nonfragmented DNA and only $0.32 \%$ have some type of DNA damage. 
Table 4

DNA integrity, related by sex and ibuprofen concentration at different times of experimentation in $P$. magdaleniatum.

\begin{tabular}{|c|c|c|c|c|c|}
\hline \multirow[t]{2}{*}{ Sex } & \multirow[t]{2}{*}{ Concentration $(\mu \mathrm{g} / \mathrm{L})$} & \multicolumn{4}{|l|}{ Time zero } \\
\hline & & $2 n(\%)$ & $4 n(\%)$ & $<2 n(\%)$ & Linearity \\
\hline & 0 control & $95.300 \pm 1.908$ & $3.880 \pm 1.600$ & $0.310 \pm 0.105$ & $1.972 \pm 0.014$ \\
\hline Female & \multirow[t]{2}{*}{25} & $94.800 \pm 0.700$ & $4.527 \pm 0.583$ & $0.087 \pm 0.064$ & $1.994 \pm 0.004$ \\
\hline Male & & $94.333 \pm 1.950$ & $4.860 \pm 1.669$ & $0.240 \pm 0.225$ & $1.962 \pm 0.019$ \\
\hline Female & \multirow[t]{2}{*}{50} & $95.750 \pm 0.212$ & $3.560 \pm 0.113$ & $0.360 \pm 0.014$ & $1.985 \pm 0.007$ \\
\hline Male & & $95.600 \pm 1.058$ & $3.590 \pm 0.670$ & $0.321 \pm 0.279$ & $1.970 \pm 0.022$ \\
\hline \multirow[t]{3}{*}{ Sex } & \multirow[t]{2}{*}{ Concentration $(\mu \mathrm{g} / \mathrm{L})$} & Four months & & & \\
\hline & & $2 n(\%)$ & $4 n(\%)$ & $<2 n(\%)$ & Linearity \\
\hline & 0 control & $91.300 \pm 0.100$ & $6.950 \pm 0.262$ & $0.395 \pm 0.114$ & $1.928 \pm 0.008$ \\
\hline Female & \multirow[t]{2}{*}{25} & $93.233 \pm 2.139$ & $5.093 \pm 2.169$ & $0.301 \pm 0.033$ & $1.927 \pm 0.020$ \\
\hline Male & & $91.567 \pm 1.210$ & $6.540 \pm 0.920$ & $0.317 \pm 0.035$ & $1.930 \pm 0.010$ \\
\hline Female & \multirow[t]{2}{*}{50} & $92.650 \pm 0.778$ & $6.135 \pm 0.573$ & $0.245 \pm 0.078$ & $1.928 \pm 0.008$ \\
\hline Male & & $92.767 \pm 2.250$ & $5.647 \pm 2.358$ & $0.301 \pm 0.092$ & $1.940 \pm 0.022$ \\
\hline \multicolumn{6}{|c|}{ Mean \pm SD. } \\
\hline
\end{tabular}

Comparing these results with other studies where DNA integrity is determined by comet assay, ibuprofen alterations were evident in monocytic cells of Hoplias malabaricus (Ribas et al. 2014); in Rhamdia quelen with ibuprofen exposure of $66.40 \mathrm{ng} / \mathrm{L}$, where a statistically significant DNA loss was obtained after 5 and 28 days of exposure of 22.74-34.32\% (Rocco et al. 2010); and in Oreochromis niloticus, where exposure to $300 \mathrm{ng} / \mathrm{L}$ ibuprofen caused genotoxic effects in both acute $(48 \mathrm{~h})$ and subchronic (10 days) exposure (Ragugnetti et al. 2011). For this study, no hypodiploid cells were evident, nor was there any loss of linearity that could be interpreted as being from DNA. It is probable that, at the concentrations at which the analysis was performed, this pharmaceutical will not cause DNA damage.

\section{Conclusions}

This study is one of the first to analyze alterations in the mitochondrial membrane potential and DNA integrity using flow cytometry. Catfish Pseudoplatystoma magdaleniatum were exposed to different concentrations (0, 25 , and $50 \mu \mathrm{g} / \mathrm{L}$ ) of ibuprofen for four months. The results for the $\Delta \Psi M$ showed a statistically significant 
difference for the medium and Low $\Delta \Psi \mathrm{M}$, but without an increase in the Low $\Delta \Psi \mathrm{M}$, which indicates at these concentration levels and exposure time, there is no loss of mitochondrial function, caused by ibuprofen. There were no alterations in the integrity of the DNA, the percentages of DNA without fragmentation were higher than $90 \%$ in all sexes, connections, and exposure times. More research is needed at different levels of ibuprofen concentration, and longer exposure times; since under the conditions of this study, it was not possible to demonstrate the effects caused by ibuprofen on $\triangle \Psi M$ and DNA integrity.

\section{Declarations}

Funding: This study was funded by the Ministry of Science, Technology, and Innovation of Colombia (grant number 111569944244).

Conflict of Interest: The authors declare that they have no conflict of interest.

Author contributions: Sara E. Gallego R, performed activities related to Methodology, Formal Analysis, Investigation, Writing - Original Draft. Gustavo A. Peñuela was involved in the Funding Acquisition, Resources, Conceptualization, Supervision, and Project Administration. All authors contributed to writing the manuscript.

Ethical approval: These species were caught with the authorizations required by current regulations, Framework Permit issued by the Autoridad Colombiana de Licencias Ambientales (ANLA) in Resolution 1461 of December 3 , 2014. All animal experiments were following Directive 2010/63/EU of the European Parliament and approved by the Ethics Committee for Animal Experimentation of the Universidad de Antioquia, with Act 89 of May 29, 2014.

\section{Availability statement}

The datasets generated during and/or analyzed during the current study are available from the corresponding author on reasonable request.

\section{References}

Aguilar-Romero I, Romero E, Wittich RM, van Dillewijn P (2020) Bacterial ecotoxicity and shifts in bacterial communities associated with the removal of ibuprofen, diclofenac and triclosan in biopurification systems. Sci Total Environ 741:140461. https://doi.org/10.1016/j.scitotenv.2020.140461

Allauca P, Ugarelli A, Santiani A (2019) Determinación del potencial de membrana mitocondrial mediante citometría de flujo durante el proceso de criopreservación de espermatozoides epididimarios de alpacas Determination of mitochondrial membrane potential by flow cytometry during the cryopreserv. Rev Inv Vet Perú 30:288-298

Alzamora-Gonzales L, de Amat-Herbozo C, Colona-Vallejos E, et al (2015) Método rápido para la cuantificación de leucocitos sanguíneos y su utilidad en la evaluación del estado de salud en trucha arcoíris Oncorhynchus mykiss. Lat Am J Aquat Res 43:1019-1023. https://doi.org/10.3856/vol43-issue5-fulltext-22

Arce JW, Alonso JC, Hernández S, Valderram M (2014) Determination of spawning characteristics and fecundity of the the Magdalena Catfish Pseudoplatystoma magdaleniatum. Biota Colomb 15:70-82 
Arias J (2019) Pharmaceutical and Personal Hygiene Products (PPcPs): A Threat Little Studied in Colombian Waters. Agric Res Technol 22:1-8. https://doi.org/10.19080/ARTOAJ.2019.22.556201

Aristizabal-Ciro C, Botero-Coy AM, López FJ, Peñuela GA (2017) Monitoring pharmaceuticals and personal care products in reservoir water used for drinking water supply. Environ Sci Pollut Res 24:7335-7347.

https://doi.org/10.1007/s11356-016-8253-1

Bedoya-Ríos DF, Lara-Borrero JA, Duque-Pardo V, et al (2018) Study of the occurrence and ecosystem danger of selected endocrine disruptors in the urban water cycle of the city of Bogotá, Colombia. J Environ Sci Heal - Part A Toxic/Hazardous Subst Environ Eng 53:317-325. https://doi.org/10.1080/10934529.2017.1401372

Blanco F, López-Armada M (2005) Papel de la mitocondria en la artrosis. Rev esp Reum (Ed impr) 32:32-36

Environmental Protection Agency (EPA), Office of Water, Office of Science and Technology, Engineering and Analysis Division (2007) Method 1694: Pharmaceuticals and Personal Care Products in Water, Soil, Sediment, and Biosolids by HPLC/MS/MS. In: US EPA. https://www.epa.gov/sites/production/files/2015-

10/documents/method_1694_2007.pdf

Friedrich-Ebert-Stiftung, Foro Nacional Ambiental (2015) ¿Para dónde va el río Magdalena? Riesgos sociales, ambientales y económicos del proyecto de navegabilidad, First. Bogotá (Colombia)

Galvis G, Mojica JI (2007) The Magdalena River fresh water fishes and fisheries. Aquat Ecosyst Heal Manag 10:127-139. https://doi.org/10.1080/14634980701357640

García-Cambero JP, Beltrán FJ, Encinas A, et al (2019) The added value of a zebrafish embryo-larval model in the assessment of wastewater tertiary treatments. Environ Sci Water Res Technol 5:2269-2279.

https://doi.org/10.1039/c9ew00411d

Giang PT, Burkina V, Sakalli S, et al (2019) Effects of Multi-Component Mixtures from Sewage Treatment Plant Effluent on Common Carp (Cyprinus carpio) under Fully Realistic Condition. Environ Manage 63:466-484. https://doi.org/10.1007/s00267-017-0964-7

Giang PT, Sakalli S, Fedorova G, et al (2018) Biomarker response, health indicators, and intestinal microbiome composition in wild brown trout (Salmo trutta m. fario L.) exposed to a sewage treatment plant effluentdominated stream. Sci Total Environ 625:1494-1509. https://doi.org/10.1016/j.scitotenv.2018.01.020

González-Mira A, Varó I, Solé M, Torreblanca A (2016) Drugs of environmental concern modify Solea senegalensis physiology and biochemistry in a temperature-dependent manner. Environ Sci Pollut Res 23:20937-20951. https://doi.org/10.1007/s11356-016-7293-x

Gracia-Lor E, Martínez M, Sancho J V, et al (2012) Multi-class determination of personal care products and pharmaceuticals in environmental and wastewater samples by ultra-high performance liquid-chromatographytandem mass spectrometry. Talanta 99:1011-1023. https://doi.org/10.1016/j.talanta.2012.07.091

Gutiérrez-Noya VM, Gómez-Oliván LM, Ramírez-Montero M del C, et al (2020) Ibuprofen at environmentally relevant concentrations alters embryonic development, induces teratogenesis and oxidative stress in Cyprinus carpio. Sci Total Environ 710:136327. https://doi.org/10.1016/j.scitotenv.2019.136327 
Hernández F, Ibáñez M, Botero-Coy AM, et al (2015) LC-QTOF MS screening of more than 1,000 licit and illicit drugs and their metabolites in wastewater and surface waters from the area of Bogotá, Colombia. Anal Bioanal Chem 407:6405-6416. https://doi.org/10.1007/s00216-015-8796-x

Herrera-Cruz E, Aristizabal-Regino J, Yepes-Blandón J, et al (2019) Evaluation of three cryoprotectants to preserve striped catfish (Pseudoplatystoma magdaleniatum ) semen. Rev Colomb Biotecnol XXI:55-62. https://doi.org/10.15446/rev.colomb.biote.v21n2.77847

Kasprzyk-Hordern B, Dinsdale RM, Guwy AJ (2009) The removal of pharmaceuticals, personal care products, endocrine disruptors and illicit drugs during wastewater treatment and its impact on the quality of receiving waters. Water Res 43:363-380. https://doi.org/10.1016/j.watres.2008.10.047

Liu N, Jin X, Feng C, et al (2020) Ecological risk assessment of fifty pharmaceuticals and personal care products (PPCPs) in Chinese surface waters: A proposed multiple-level system. Environ Int 136:105454. https://doi.org/10.1016/j.envint.2019.105454

Luna-Ortiz P, El-Hafidi M, Martínez-Rosas M (2013) La función mitocondrial y la cardioprotección. Rev Mex Anestesiol 36:294-305

Mathias FT, Fockink DH, Disner GR, et al (2018) Effects of low concentrations of ibuprofen on freshwater fish Rhamdia quelen. Environ Toxicol Pharmacol 59:105-113. https://doi.org/10.1016/j.etap.2018.03.008

Meijide FJ, Da Cuña RH, Prieto JP, et al (2018) Effects of waterborne exposure to the antidepressant fluoxetine on swimming, shoaling and anxiety behaviours of the mosquitofish Gambusia holbrooki. Ecotoxicol Environ Saf 163:646-655. https://doi.org/10.1016/j.ecoenv.2018.07.085

Mojica J, Usma J, Álvarez R, Lasso CA (2012) Libro rojo de peces dulceacuícolas de Colombia 2012. Bogotá (Colombia)

Mojica J, Valderrama M, Jimenez-Segura L, Alonso JC (2016) Pseudoplatystoma magdaleniatum. In: IUCN Red List Threat. Species. http://dx.doi.org/10.2305/IUCN.UK.2016-1.RLTS.T58439165A61474168.en

Montagner CC, Jardim WF (2011) Spatial and seasonal variations of pharmaceuticals and endocrine disruptors in the Atibaia River, Sao Paulo State (Brazil). J Braz Chem Soc 22:1452-1462

Motov S, Butt M, Masoudi A, et al (2020) Comparison of Oral Ibuprofen and Acetaminophen with Either Analgesic Alone for Pediatric Emergency Department Patients with Acute Pain. J Emerg Med 58:725-732. https://doi.org/10.1016/j.jemermed.2020.02.010

Ngo VTH, Bajaj T (2020) Ibuprofen. In: ncbi (ed) StatPearls. StatPearls Publishing

Noreña-Ramirez DA, Murillo-Perea E, Guio-Duque JA, Arteaga JJM- (2012) Heavy metals (Cd, Pb and Ni) in fish species commercially important from Magdalena river, Tolima tract, Colombia. Rev Tumbaga 2:61-76

Official Journal of the European Union (2010) Directive 2010/63/EU of the European Parliament and of The Council of 22 September 2010 on the protection of animals used for scientific purposes. L 276/33-79

$(20.10 .2010)$

Page $14 / 16$ 
Padmini E, Usha Rani M (2011) Mitochondrial membrane potential is a suitable candidate for assessing pollution toxicity in fish. Sci Total Environ 409:3687-3700. https://doi.org/10.1016/j.scitotenv.2011.06.020

Palacio J (2009) Biologic characteristics of blanquillo Sorubim cuspicaudus Littmann, Burr and Nass, 2000 and bagre rayado Pseudoplatystoma magdaleniatum Buitrago-Suárez and Burr, 2007 (Siluriformes: Pimelodidae) related to their reproduction in the middle basin of the Ma. Actual Biológicas 31:53-66

Parolini M (2020) Toxicity of the Non-Steroidal Anti-Inflammatory Drugs (NSAIDs) acetylsalicylic acid, paracetamol, diclofenac, ibuprofen and naproxen towards freshwater invertebrates: A review. Sci Total Environ 740:140043. https://doi.org/10.1016/j.scitotenv.2020.140043

Pemberthy D, Padilla Y, Echeverri A, Peñuela GA (2020) Monitoring pharmaceuticals and personal care products in water and fish from the Gulf of Urabá, Colombia. Heliyon 6:. https://doi.org/10.1016/j.heliyon.2020.e04215

Petrie B, Barden R, Kasprzyk Hordern B (2014) A review on emerging contaminants in wastewaters and the environment: Current knowledge, understudied areas and recommendations for future monitoring. Water Res 72:3-27

Ragugnetti M, Adams ML, Guimarães ATB, et al (2011) Ibuprofen genotoxicity in aquatic environment: An experimental model using Oreochromis niloticus. Water Air Soil Pollut 218:361-364.

https://doi.org/10.1007/s11270-010-0698-0

Restrepo G, Varela E, Duque JE, et al (2019) Freezing, Vitrification, and Freeze-Drying of Equine Spermatozoa: Impact on Mitochondrial Membrane Potential, Lipid Peroxidation, and DNA Integrity. J Equine Vet Sci 72:8-15. https://doi.org/10.1016/j.jevs.2018.10.006

Ribas JLC, da Silva CA, de Andrade L, et al (2014) Effects of anti-inflammatory drugs in primary kidney cell culture of a freshwater fish. Fish Shellfish Immunol 40:296-303. https://doi.org/10.1016/j.fsi.2014.07.009

Rice E, Baird R, Eaton A (2017a) 2320 Alkalinity. In: Standard Methods for the examination of water and wastewater, 23rd edn. American Public Health Association, American Water Works Association, Water Environment Federation

Rice E, Baird R, Eaton A (2017b) 2340 Hardness. In: Standard Methods for the examination of water and wastewater, 23rd edn. American Public Health Association, American Water Works Association, Water Environment Federation

Rice E, Baird R, Eaton A (2017c) 2540 Solids. In: Standard Methods for the examination of water and wastewater, 23rd edn. American Public Health Association, American Water Works Association, Water Environment Federation

Rieger AM, Nelson KL, Konowalchuk JD, Barreda DR (2011) Modified annexin V/propidium iodide apoptosis assay for accurate assessment of cell death. J Vis Exp 3-6. https://doi.org/10.3791/2597

Rocco L, Frenzilli G, Fusco D, et al (2010) Evaluation of zebrafish DNA integrity after exposure to pharmacological agents present in aquatic environments. Ecotoxicol Environ Saf 73:1530-1536. https://doi.org/10.1016/j.ecoenv.2010.07.032

Page $15 / 16$ 
Rojas M, Garcı LF, Puzo G, Olivier M (2000) tuberculosis - Induced Macrophage Apoptosis by Altering Ca + 2 Dependent Cell Signaling. J Infect Dis 182:240-251

Santamaría Merchán SC (2013) Nutrición y Alimentación en Peces Nativos. Universidad Nacional Abierta y a Distancia

Saravanan M, Devi KU, Malarvizhi A, Ramesh M (2012) Effects of Ibuprofen on hematological, biochemical and enzymological parameters of blood in an Indian major carp, Cirrhinus mrigala. Environ Toxicol Pharmacol 34:14-22. https://doi.org/10.1016/j.etap.2012.02.005

Sathishkumar P, Meena RAA, Palanisami T, et al (2020) Occurrence, interactive effects and ecological risk of diclofenac in environmental compartments and biota - a review. Sci Total Environ 698:134057. https://doi.org/10.1016/j.scitotenv.2019.134057

Tejeda-Benitez L, Flegal R, Odigie K, Olivero-Verbel J (2016) Pollution by metals and toxicity assessment using Caenorhabditis elegans in sediments from the Magdalena River, Colombia. Environ Pollut 212:238-250. https://doi.org/10.1016/j.envpol.2016.01.057

Tejeda-Benítez L, Noguera-Oviedo K, Aga DS, Olivero-Verbel J (2018) Toxicity profile of organic extracts from Magdalena River sediments. Environ Sci Pollut Res 25:1519-1532. https://doi.org/10.1007/s11356-017-0364-9

Tiedeken EJ, Tahar A, McHugh B, Rowan NJ (2017) Monitoring, sources, receptors, and control measures for three European Union watch list substances of emerging concern in receiving waters - A 20 year systematic review. Sci Total Environ 574:1140-1163. https://doi.org/http://dx.doi.org/10.1016/j.scitotenv.2016.09.084

Xia L, Zheng L, Zhou JL (2017) Effects of ibuprofen, diclofenac and paracetamol on hatch and motor behavior in developing zebrafish (Danio rerio). Chemosphere 182:416-425.

https://doi.org/10.1016/j.chemosphere.2017.05.054

Zapata LA, Usma JS, Rodríguez T, et al (2015) Recursos pesqueros de Colombia, principales especies, conservación y pesca responsable. AUNAP, WWF Colombia, Cali (Colombia)

Zhang K, Yuan G, Werdich AA, Zhao Y (2019) Ibuprofen and diclofenac impair the cardiovascular development of zebrafish (Danio rerio) at low concentrations. Environ Pollut 113613.

https://doi.org/10.1016/j.envpol.2019.113613

Zorova LD, Popkov VA, Plotnikov Y, et al (2018) Mitochondrial membrane potential HHS Public Access Author manuscript. Anal Biochem 552:50-59. https://doi.org/10.1016/j.ab.2017.07.009 